\title{
Valorisation of Sidestream from lithium Refining - Activation of Analcime
}

\author{
Esther Takaluoma, Tatiana Samarina \\ Kajaani University of Applied Sciences \\ Ketunpolku 1, PL 52, 87101, Kajaani, Finland \\ esther.takaluoma@kamk.fi; tatiana.samarina@kamk.fi
}

\section{Extended Abstract}

The European Union has an ambitious goal to transition from linear to circular economy [1]. In circular economy, the old saying of "one's waste is the other's treasure" is being implemented. An industrial side stream, traditionally branded as waste, is the raw material for the formation of the next product. Analcime is a reject from spodumene refining at a Finnish lithium hydroxide plant, currently in piloting stage, but is also found as a natural zeolite. With a channel size of $4.2-8.9 \AA$ [2], analcime can be used as sodium cation exchange for $\mathrm{NH}_{4}^{+}[3], \mathrm{Pb}^{2+}$ and $\mathrm{Cu}^{2+}$ [4], and to a lesser extent and at elevated temperatures for $\mathrm{K}^{+}, \mathrm{Ag}^{+}, \mathrm{Tl}^{+}, \mathrm{Rb}^{+}[5]$.

Being an energy minimum, the $\alpha$-analcime structure is inert towards mild activation methods. Therefore, in this paper the valorisation of analcime by thermal and chemical activation and possible ways of obtained materials' use are discussed. Several procedures were considered in order to change raw material properties: alkaline, acid, and thermal activation.

Raw analcime is inert towards alkaline activation (geopolymerisation) under all room temperature reaction in a solid to liquid ratio of $1: 1.1$ with $\mathrm{NaOH} / \mathrm{NaSiO}_{3}$ or $\mathrm{KOH} / \mathrm{KSiO}_{3}$ solution. Rinsing with 1 and $2 \mathrm{M} \mathrm{HCl}$ did not facilitate the geopolymerization, nor did heating at $700{ }^{\circ} \mathrm{C}$. Calcination at $900{ }^{\circ} \mathrm{C}$ for $2 \mathrm{~h}$ resulted in complete phase change from analcime to nepheline, as characterized by XRD. Treating analcime with sulfuric acid of at 3, 4, and $5 \mathrm{M}$ strength resulted in breakdown of the alumino-silicate structure of analcime and the formation of $\mathrm{Na}_{2} \mathrm{AlSO}_{4}$. XRD and XRF confirm the preferential dissolution of aluminate. After acid activation, geopolymerization occurred rapid and exothermic. Mixing analcime with metakaolinite as an additional binder had also resulted in the geopolymerized solid material. The structural properties, XRF, and XRD characterization of activated analcime products are discussed.

Adsorptive properties of the new materials were tested for ammonium and compared to the raw side stream analcime. In all cases, the ammonium sorption were low. Activation with $5 \mathrm{M} \mathrm{H}_{2} \mathrm{SO}_{4}$ and subsequent geopolymerization (adsorbent ANA-5M-GP) doubles the adsorption capacity at $50 \mathrm{mg} / \mathrm{L} \mathrm{NH}_{4}{ }^{+}$and dose of 2 and $5 \mathrm{~g} / \mathrm{L}$. The competition of ion exchange sites $\mathrm{Ca}^{2+}$ cations at concentrations found in municipal wastewater $\left(40-100 \mathrm{mg} / \mathrm{L} \mathrm{Ca}^{2+}\right)$ is discussed and investigated under complex matrix of Kajaani municipal waste water.

Inert analcime side stream can undergo harsh chemical and thermal treatment to form new products with potentially interesting properties. Geopolymerization of acid treated activation of inert analcime greatly influences the structural and chemical properties of the raw substance. ANA-5M-GP has a higher adsorption capacity for ammonium than raw analcime. Additionally, the fast geopolymerization reaction could find applications in fast-hardening low carbon concrete substituents. Acid activation with at least $3 \mathrm{M} \mathrm{H}_{2} \mathrm{SO}_{4}$ therefore valorises the side product and enhances its properties for new applications in terms of circular economy.

This study was conducted as a part of the KAKKU project (number A74868 EAKR, Kainuun Liitto).

\section{References}

[1] "New Circular Economy Strategy - Environment - European Commission." https://ec.europa.eu/environment/circulareconomy/ (accessed Jun. 18, 2020).

[2] F. Mazzi and E. Galli, "Is each analcime different? ANA 4," $1978 . \quad$ [Online]. Available: http://www.crystallography.net/cod/9000645.html. 
[3] Y. Wang and F. Lin, "Synthesis of high capacity cation exchangers from a low-grade Chinese natural zeolite," $J$. Hazard. Mater., vol. 166, no. 2-3, pp. 1014-1019, 2009.

[4] S. Tangkawanit, K. Rangsriwatananon, and A. Dyer, "Ion exchange of $\mathrm{Cu} 2+, \mathrm{Ni2}+, \mathrm{Pb} 2+$ and $\mathrm{Zn} 2+$ in analcime (ANA) synthesized from Thai perlite," Microporous Mesoporous Mater., vol. 79, no. 1, pp. 171-175, 2005.

[5] R. M. Barrer and L. Hinds, "386. Ion-exchange in crystals of analcite and leucite," J. Chem. Soc. Resumed, pp. 1879$1888,1953$. 